\title{
Peluang tanaman Suweg/Maek (Amorphophallus paeoniifolius Dennst) dan Porang/Maek Bako (Amorphophallus muelleri) sebagai komoditas ekonomi dan pangan lokal di Kabupaten Belu
}

\author{
Opportunities for Suweg/Maek (Amorphophallus \\ paeoniifolius Dennst) and Porang/Maek Bako \\ (Amorphophallus muelleri) plants as local food and economic \\ commodities in Belu Regency
}

\author{
Mariano A. T. Nugraha \\ Badan Perencanaan Pembangunan Penelitian dan Pengembangan Daerah \\ Provinsi Nusa Tenggara Timur \\ E-mail: nugraharinto45@gmail.com \\ Naskah Diterima : 24 Juni 2020; Di-review : 02 Juli 2020; Dimuat: Agustus 2020
}

DOI 10.46888/flobamora.v3i1.49

Copyright @FLOBAMORA 2020

\begin{abstract}
This study aimed to assess opportunities of local food Suweg/Maek and Porang/Maek Bako as potential economic commodities by providing a systematic understanding of their species distribution, showing their similarities and differences in nutritional content, and analyzing their impact on local economic context. A descriptive analysis was performed while applying small scale laboratory analysis. Direct observation and interview were applied to collect data through a period of survey. A total of 80 respondents (10 respondents of each sub-district) were recruited using snowball sampling technique in South Lamaknen, Lamaknen, Lasiolat, Nanae Dua Besi, Raimanuk, Raihat, West Tasifeto, and East Tasifeto. The primary data were collected by interviewing key respondents and secondary data were obtained from related agencies and records. Data were collected, coded, and tabulated accordingly. Then analyzed in both qualitative and quantitative aspects including plants morphology, Global Positioning System (GPS) analysis and distribution, production analysis (cost analysis, local food consumption patterns). The findings were discussed in terms of their impact as potential commodities. The results show that Maek and Maek Bako have potential economic benefits, good nutritional content for local fresh food and alternatives, and valuable for food planning. It is essential that Belu Government should support their (unused) potential with adequate financial support, technology diffusion, and enhancing public private collaboration to increase the plants productivity.
\end{abstract}

Keywords : Opportunities, Economic Commodities, Local Food, Maek, Maek Bako

Abstrak

Penelitian ini mau melihat peluang tanaman Suweg/Maek dan Porang/Maek Bako sebagai komoditas ekonomi dan pangan lokal dilihat dari pengidentifikasian jenis dan memetakan sebarannya, menganalisis peluang ekonomi dan menganalisis kandungan gizi kedua jenis tanaman tersebut. Penelitian ini bersifat deskriptif dengan menggunakan metode survey dengan metode pengumpulan data primer yang diperoleh melalui analisis laboratorium, observasi langsung, wawancara dan transek garis dengan responden yang dipilih secara purposive snowball sampling sebanyak 10 orang setiap kecamatan pada 8 (delapan) Kecamatan yaitu Kecamatan Lamaknen Selatan, Lamaknen, Lasiolat, Nanaet Dua Besi, Raimanuk, Raihat, Kecamatan Tasifeto Barat, dan Kecamatan Tasifeto Timur, yang merupakan tokoh kunci atau tokoh masyarakat yang mengetahui dan mengkonsumsi Maek dan Maek Bako, sedangkan data sekunder diperoleh dari hasil studi 
pustaka/dokumentasi pada dinas/instansi terkait. Analisa data dilakukan mulai dari proses pengolahan data meliputi pemeriksaan data (editing), memberi kode (coding) dan tabulasi data (coding). Kemudian dilakukan analisa data mengggunakan analisa data kualitatif dan kuantitatif meliputi analisis deskriptif morfologis jenis-jenis Maek dan Maek boko yang tumbuh, analisis Global Positioning System (GPS) dan pemetaan sebaran tanaman Maek dan Maek Bako, analisis produksi melalui analisa populasi dengan metode transek garis, analisis biaya produksi, analisis peneriman dan pendapatan, analisis kelayakan usaha, analisis laboratorium dan analisis pola konsumsi pangan lokal. Hasil penelitian ini menemukan bahwa Maek dan Maek Bako budidaya maupun non budidaya memiliki potensi dan manfaat ekonomi yang layak untuk masyarakat serta memiliki kandungan gizi yang baik untuk dijadikan pangan lokal alternatif maupun ekonomis untuk menunjang pendapatan masyarakat. Diharapkan Pemerintah Kabupaten Belu dapat mendukung dengan alokasi anggaran, mempersiapkan teknologi tepat guna dan bekerjasama dengan pihak swasta untuk mendukung peningkatan produktivitas hasil Maek dan Maek Bako.

Kata Kunci : Peluang, Komoditas Ekonomi, Pangan Lokal, Maek, Maek Bako

\section{Pendahuluan}

Pangan dan gizi merupakan unsur yang sangat penting dan strategis dalam meningkatkan sumber daya manusia yang berkualitas, karena pangan selain mempunyai arti biologis juga mempunyai arti ekonomis dan politis (Navin, 2014; Peterson, 2013; Roehrig, 2011; Schnell, 2013). Implikasinya bahwa penyediaan, distribusi dan konsumsi pangan dengan jumlah, keamanan dan mutu gizi yang memadai harus terjamin, sehingga dapat memenuhi kebutuhan penduduk secara keseluruhan pada setiap saat sesuai dengan pola makan dan keinginan mereka agar sehat dan aktif (Bryld, 2003; Carney et al., 2012; Conroe, 1999; Maughan, Pedersen, \& Pitt, 2018; Navin, 2014).

Dalam upaya membangun Sumber Daya Manusia yang berkualitas, perlu didorong perilaku dan kebiasaan masyarakat agar memiliki budaya makan dan hidup sehat. Hal ini dipandang perlu digalakkan penganekaragaman pangan serta mengembangkan sikap dan perilaku keluarga dan masyarakat agar tetap menyukai makanan lokal, meningkatkan pendapatan dengan perluasan lapangan pekerjaan dan kesempatan berusaha serta upaya lainnya sesuai kebutuhan masyarakat (Schnell, 2013; Trivette, 2015; Zeuw, Veenhuizen, \& Dubbeling, 2011).

Dalam kehidupan sehari-hari, setiap orang dapat memenuhi kebutuhan gizi melalui konsumsi pangan dalam jumlah yang beragam, bergizi, seimbang dan aman (B2SA). Zat gizi yang diperlukan oleh tubuh meliputi karbohidrat, lemak, protein, vitamin, dan mineral yang diperoleh manusia dari pangan, yaitu melalui makanan dan minuman yang dikonsumsinya.

Suweg (Amorphophallus paeoniifolius Dennst), dan Porang (Amorphophallus muelleri B.) merupakan tanaman umbi-umbian dari keluarga Arasease yang mampu hidup pada beragai jenis kondisi tanah, termasuk lahan marginal. Suweg dan porang merupakan tanaman umbi-umbian minor yang jarang dibudidayakan. Namun, seiring bertambahnya jumlah penduduk dan terbatasnya lahan pertanian yang subur, maka dua jenis tanaman ini dapat menjadi alternatif dalam program diversifikasi pangan, selain karena kandungan gizinya yang tidak kalah dengan umbi-umbian lain seperti kentang, ubi kayu dan ubi jalar, juga karena tanaman ini mampu tumbuh dan berproduksi pada kondisi intensitas cahaya rendah, misalnya di bawah tegakan hutan. Dengan demikian maka tanaman suweg dan porang dapat dijadikan sebagai pangan lokal alternatif, bernilai ekonomis, sekaligus mengatasi persoalan keterbatasan lahan pertanian (Björk \& Kauppinen-Räisänen, 2016; Charatsari, Kitsios, Stafyla, Aidonis, \& Lioutas, 2018; Dimitri, Oberholtzer, \& Pressman, 2015; Pearson, Pearson, \& Pearson, 2010; Peterson, 2013).

Di Kabupaten Belu, tanaman Maek dan Maek Bako dapat ditemui tumbuh liar hampir di setiap tempat di daerah ini, dan belum dibudidayakan oleh masyarakat. Umbi suweg dan porang umumnya hanya dimanfaatkan sebagai pangan alternatif terutama pada masa-masa paceklik, dimana ketersediaan pangan utama seperti jagung, padi dan umbi-umbian lainnya tidak mencukupi kebutuhan. Umbi Maek/suweg dapat dikonsumsi langsung setelah melalui tahapan perendaman dan perebusan sedangkan umbi Maek Bako/porang yang biasanya mengandung rasa gatal perlu diberi perlakuan khusus seperti penjemuran, dan lain-lain untuk menghilangkan rasa gatal sebelum dimasak untuk konsumsi atau dibuat tepung untuk pangan olahan lainnya.

Di beberapa tempat, Maek dan Maek Bako juga sudah mulai memiliki nilai ekonomis karena sudah dilirik oleh pasar luar daerah sebagai bahan baku industri dan farmasi. Dari Gambaran di atas menunjukan bahwa selama ini Maek dan Maek Bako yang dianggap sebagai tanaman minor, memiliki potensi untuk dikembangkan sebagai pangan lokal sumber karbohidrat dan juga sebagai komoditas ekonomi.

Sementara itu, potensi Maek dan Maek Bako sebagai komoditi ekonomis dan pangan lokal di Kabupaten Belu hingga saat ini belum diketahui karena belum ada kajian akademik tentang hal itu. Maek dan Maek Bako berada pada genus yang sama dalam taksonomi tumbuhan, yakni genus Amorphophallus sehingga memiliki banyak kemiripan ciri morfologis. Namun demikian, oleh karena keduanya berbeda spesies maka secara 
otomatis memiliki perbedaan-perbedaan, termasuk aspek morfologi, kandungan gizi serta senyawa kimia dalam umbi. Kedua tanaman ini juga kadang sulit dibedakan secara cepat dengan anggota genus yang sama yakni iles-iles (Amorphophallus variabilis), yang walaupun masih sekerabat tetapi memiliki perbedaan dalam banyak hal. Dengan demikian, maka perlu dilakukan kajian tentang keberadaan dan sebaran Maek dan Maek Bako serta potensinya sebagai komoditas ekonomis dan pangan lokal di Kabupaten Belu, untuk selanjutnya dapat dikembangkan dan dimanfaatkan secara optimal.

\section{Metodologi}

\subsection{Metode Pengumpulan Data}

Penelitian ini bersifat deskriptif dengan menggunakan metode survey dengan metode pengumpulan data primer yang diperoleh melalui analisis laboratorium untuk mengetahui kandungan energi (kkal), karbohidrat (gram), protein (gram), lemak (gram), Bagian yg Dapat Dimakan/BDD (\%), air (\%), abu (\%), Cu (gram) dan Fe (gram), observasi langsung, wawancara dan transek garis dengan responden yang dipilih secara purposive snowball sampling sebanyak 10 orang setiap kecamatan pada 8 (delapan) Kecamatan yaitu Kecamatan Lamaknen Selatan, Lamaknen, Lasiolat, Nanaet Dua besi, Raimanuk, Raihat, KecamatanTasifeto Barat, dan Kecamatan Tasifeto Timur, yang merupakan tokoh kunci atau tokoh masyarakat yang mengetahui dan mengkonsumsi Maek (Amorphophallus paeoniifolius Dennst, Nicolson) dan Maek Bako (Amorphophallus muelleri B.), sedangkan data sekunder diperoleh dari hasil studi pustaka/dokumentasi pada dinas/instansi terkait.

\subsection{Analisis Data}

Analisa data dilakukan mulai dari proses pengolahan data meliputi pemeriksaan data (editing), memberi kode (coding) dan tabulasi data (coding). Kemudian dilakukan analisa data mengggunakan analisa data kualitatif dan kuantitatif meliputi analisis deskriptif morfologis jenis-jenis Maek dan Maek Bako yang tumbuh., analisis Global Positioning System (GPS) dan pemetaan sebaran tanaman Maek dan Maek Bako, analisis produksi melalui analisa populasi dengan metode transek garis, analisis biaya produksi, analisis peneriman dan pendapatan, analisis kelayakan usaha, analisis laboratorium dan analisis pola konsumsi pangan lokal.

\section{Hasil dan Pembahasan}

\subsection{Morfologis dan Sebaran Suweg (Maek) dan} Porang (Maek Bako)

3.1.1. Identifikasi Morfologis Suweg (Maek) dan Porang (Maek Bako)

\subsubsection{Hasil wawancara dengan responden kunci}

Hasil wawancara dengan responden kunci di delapan kecamatan di Kabupaten Belu dapat dirangkum sebagai berikut:

a. Jenis-jenis tanaman dalam genus Amorphophalus yang ada di lapangan terdiri dua jenis, yang dalam bahasa lokal di Kecamatan Lamaknen dan Kecamatan Lamaknen Selatan disebut Me Loi dan Me Jon, sedangkan di Kecamatan Nanaet Duabesi dan Kecamatan Raimanuk disebut Maek Diak, Maek Fuik dan Maek Bako.

b. Ciri morfologis Me Loi dan Maek Diak, seperti yang disampaikan oleh reponden, memiliki kesamaan yakni: tangkai daun (batang semu): teksturnya agak kasar dengan bercak putih berbentuk bulat, umbinya tidak berasa gatal, dan tidak ada bulbil pada ruas daunnya. Sementara itu, ciri morfologis Me Jon memiliki kesamaan dengan Maek Bako, yakni: tekstur tangkai daun (batang semu) licin, agak kasar, dengan bercak putih berbentuk belah ketupat, umbinya berasa gatal, serta ada bulbil pada ruas daunnya. Berdasarkan deskripsi morfologis tersebut, maka selanjutnya digunakan dua istilah untuk dua jenis Amorphophalus yang ada di lapangan yakni Maek untuk Me Loi/ Maek Diak dan Maek Bako untuk Me Jon/Maek Bako.

c. Berdasarkan ciri-ciri morfologis yang ada pada acuan pustaka/ literatur, maka ciri-ciri morfologis yang dideskripsikan oleh responden untuk Maek (walaupun tidak lengkap) memiliki kesamaan dengan ciri morfologis Suweg sedangkan ciri morfologis Maek Bako sama dengan ciri morfologis Porang. Oleh karena itu, untuk kemudahan identifikasi dan pengenalan, maka penggunaan istalah Maek cenderung disamakan dengan Suweg sedangkan Maek Bako sama dengan Porang. Namun, untuk memastikan bahwa Maek adalah betul-betul Suweg (Amorphophallus paeoniifolius Dennst) dan Maek Bako adalah benar-benar Porang (Amorphophallus muelleri B.), maka perlu dilakukan pengamatan morfologis secara lengkap, yang akan disajikan pada bagian berikut.

3.1.3. Hasil Pengamatan Morfologis di Lapangan

Pengamatan lapangan dilakukan di delapan kecamatan, masing-masing satu desa sebagai lokasi pengamatan. Pengamatan terhadap Maek dan Maek Bako dilakukan di lokasi hutan, di mana tanaman ini tumbuh secara liar. Fakta di lapangan juga menunjukkan bahwa tanaman Maek Bako juga kebanyakan ditemukan di sekitar pekarangan rumah atau kebun, karena tanaman ini sudah dibudidaya oleh masyarakat dalam beberapa tahun terakhir.

Hasil pengamatan lapangan terhadap morfologi kuncup bunga Maek/Maek Bako [tanda garis miring (/) digunakan untuk menyatakan bahwa pada tahap ini, belum dapat dipastikan apakah yang diamati itu 
adalah Maek atau Maek Bako], disajikan pada Gambar 1.

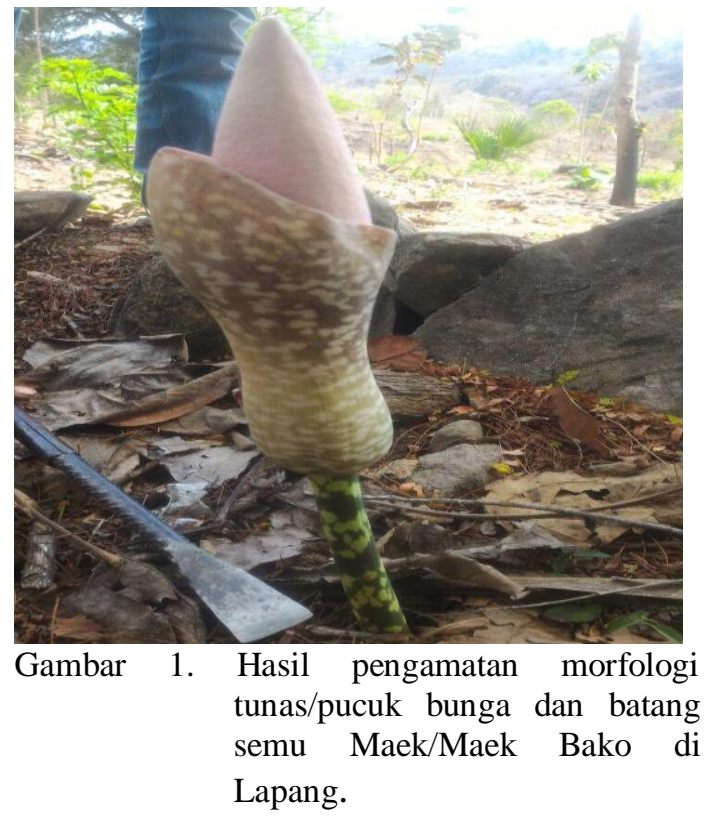

Penampilan morfologis tunas dan batang semu pada Gambar 1 menunjukkan adanya bercak-bercak berwarna putih dengan bentuk yang menyerupai bercak-bercak pada Suweg dan Porang. Menurut penuturan responden kunci, gambar kuncup bunga yang ditampilkan pada Gambar 1 adalah Maek Bako. Jika ditilik secara saksama, maka kelihatan bahwa bercak putih pada batang semu maupun mahkota bunga berbentuk tidak beraturan, namun ada yang mirip belah ketupat. Tidak ada sama sekali bercak putih berbentuk bulat (ciri morfologis batang semua Maek/Suweg) sehingga dapat dikatakan bahwa yang ada pada Gambar 1 adalah Maek Bako/Porang, sesuai pengakuan responden kunci. Kalaupun mungkin ada Maek/Suweg di sekitar lokasi penelitian, namun pada saat penelitian tidak ditemukan adanya fase pertumbuhan tunas/pucuk bunga di sekitar lokasi pengamatan.

Selain kuncup bunga, tim peneliti juga berhasil melakukan dokumentasi terhadap umbi dan tunas yang baru tumbuh di lapang (Gambar 2). Gambar 2 menunjukan tunas yang baru tumbuh dari mata tunas umbi. Berdasarkan karakteristik morfologis yang sudah dipublikasi, baik Maek/suweg maupun Maek Bako/porang, masing-masing memiliki tunas umbi, dan yang berbeda adalah jumlah mata tunas, yang tunggal pada porang dan bisa lebih dari satu pada suweg. Terlihat pada gambar 2 bahwa tunas yang tumbuh berasal dari mata tunas utama dan tidak terlihat jumlah mata tunas yang lainnya sehingga, sekali lagi, berdasarkan tunas umbi yang tumbuh belum bisa dipastikan apakah itu Maek atau Maek Bako.

Bobot umbi Maek/Maek Bako pada saat pengamatan (Gambar 3) berkisar 3-5 kg per umbi pada tanaman, yang menurut pengakuan respinden kunci, berumur sekitar tiga tahun.

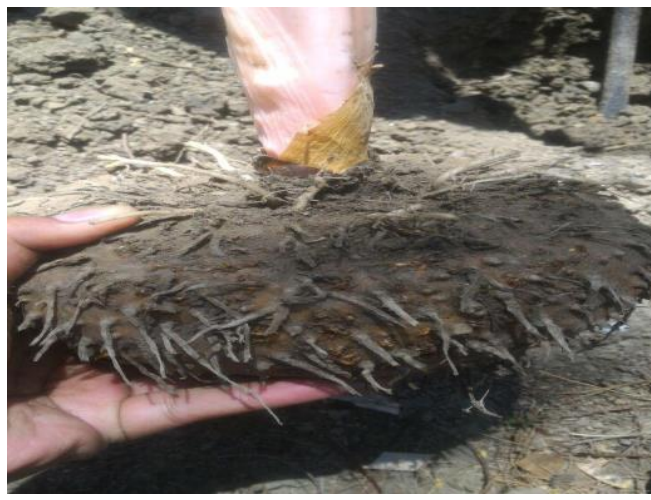

Gambar 2. Morfologi umbi dan tunas umbi Maek/Maek Bako yang diamati di lapangan.

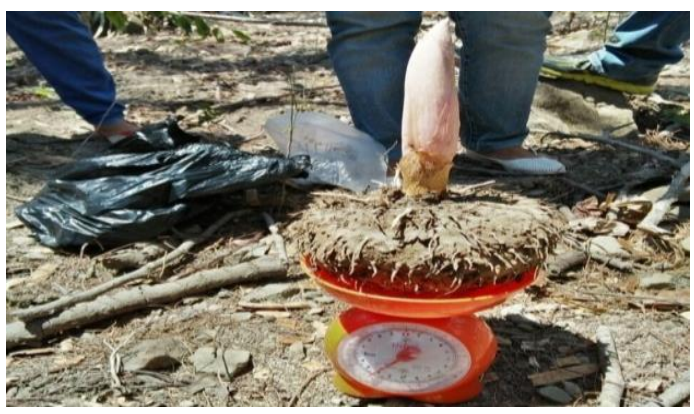

Gambar 3. Bobot umbi dan tunas umbi Maek/Maek Bako yang diamati di lapangan.

Untuk memastikan keberadaan Maek/Maek Bako di lokasi penelitian, perlu dilakukan konfirmasi lanjutan pada bentuk dan permukaan umbi serta warna daging umbi, serta ada tidaknya rasa gatal. Konfirmasi lanjutan terhadap bentuk umbi didasarkan pada hasil pengamatan pada Gambar 4.

Bentuk umbi dan warna daging umbi yang disajikan pada Gambar 4, sebelum didokumentasi, didahului dengan wawancara melibatkan tokoh kunci yang mengetahui secara baik tentang Maek dan Maek Bako. Berdasarkan pengakuan tokoh kunci, diketahui bahwa umbi pada Gambar 4a merupakan Maek (suweg) dengan ciri permukaan umbi yang agak kasar dan warna coklat keabu-abuan, serta tidak ada rasa gatal. Hal ini mereka ketahui karena mereka sudah sering mengkonsumsi Maek ini, terutama pada masa-masa paceklik. Sementara itu, Maek Bako (Gambar 4b), menurut responden kunci, memiliki permukaan umbi kasar dan ada rasa gatal sehingga mereka tidak mengkonsumsinya. Pengakuan responden kunci ini sesuai dengan ciri morfologis umbi suweg dan porang yang sudah dipublikasi secara ilmiah. Dengan demikian maka dapat dipastikan bahwa umbi pada Gambar 4a adalah Maek sedangkan umbi pada Gambar 4b adalah Maek Bako. 


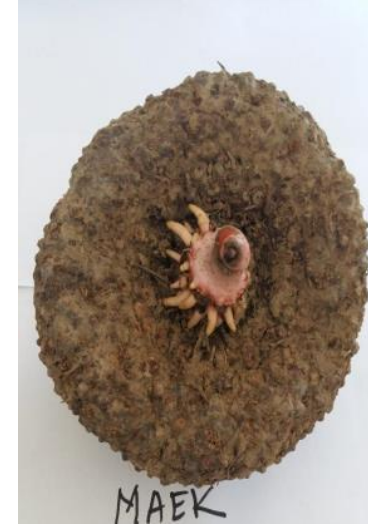

Gambar 4a. Maek

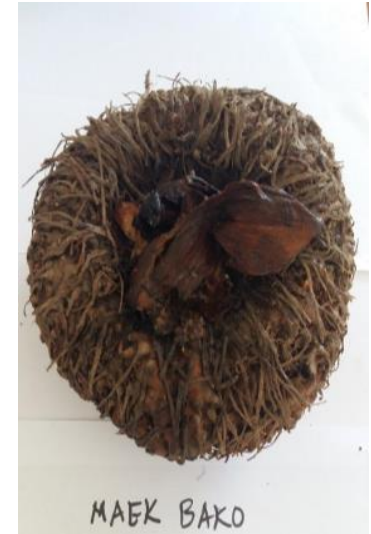

Gambar 4b. Maek Bako

Pada saat umbi dibelah, penampilan daging umbi Maek dan Maek Bako tampak seperti tersaji pada Gambar 4c dan 4d. Terlihat pada gambar bahwa, baik Maek maupun Maek Bako memiliki warna daging umbi putih kekuningan. Warna daging umbi Maek pada gambar 4c agak berbeda dengan deskripsi suweg yang sudah dipublikasi yakni putih bercampur merah jambu. Namun, hal ini bukan berarti bahwa umbi pada Gambar 4c bukan Maek/Suweg karena bisa saja terjadi variasi pada warna daging umbi karena perbedaan faktor lingkungan tumbuh. Walapun warna daging umbi Maek tidak konsisten dengan deskripsi warna daging umbi Suweg, namun karakter morfologis lain memiliki kesamaan sehingga dapat dikatakan bahwa Maek (istilah lokal Belu) sesungguhnya adalah Suweg (istilah Jawa yang sudah jadi istilah umum) untuk A. paeoniifolius.

Gambar 4d menunjukkan warna daging Maek Bako yang kuning terang dan persis sama dengan deskripsi warna daging umbi Porang yang sudah dipublikasi. Dengan demikian, berdasarkan deskripsi morfologis yang diamati dalam penelitian ini, baik berdasarkan hasil wawancara maupun hasil pengamatan langsung, maka dapat dikatakan bahwa Maek Bako dalam bahasa lokal Belu sesungguhnya adalah Porang (A. muelleri).

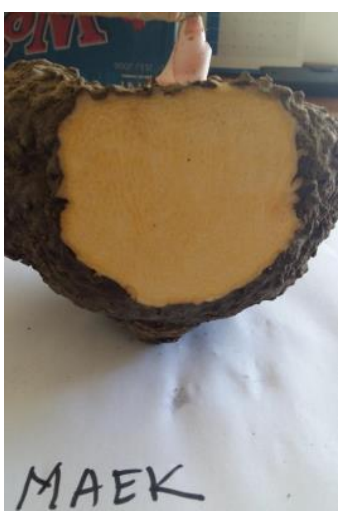

Gambar 4c. Warna daging Maek

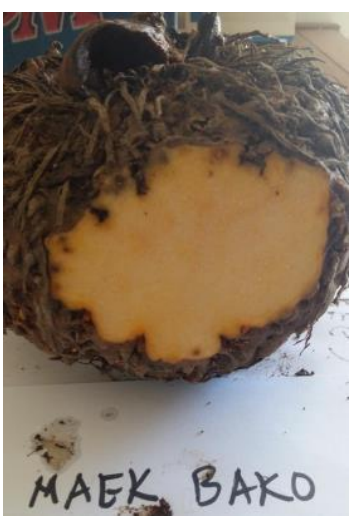

Gambar 4d. Warna daging Maek Bako
Berdasarkan uraian di atas, baik hasil wawancara maupun pengamatan langsung terhadap ciri morfologis tanaman di lapangan, maka dapat diidentifikasi dua jenis tanaman talas-talasan genus Amorphophalus di Kabupaten Belu yakni Maek (Me Loin/Maek Diak) atau Suweg (Amorphophallus paeoniifolius Dennst) dan Maek Bako (Me Jon/Maek Fuik) atau Porang (Amorphophallus muelleri B.).

\subsection{Sebaran Maek dan Maek Bako di Kabupaten Belu}

Hasil wawancara dengan responden dan pengamatan langsung di lapang menunjukkan bahwa Maek dan Maek Bako menyebar di semua kecamatan (delapan kecamatan) yang dijadikan sebagai lokasi penelitian, dengan tingkat kepadatan sebaran yang berbeda-beda.

Secara habitat lokal, Maek ditemukan tumbuh secara berkoloni/berumpun di area hutan, semak belukar, dan kebun dengan jumlah populasi yang bervariasi antar lokasi sebaran, tergantung keadaan iklim mikronya. Namun, secara rata-rata ditemukan sekitar 4-5 pohon/2 $\mathrm{m}^{2}$ atau sekitar 20-30 pohon per luasan 1 are.

Jumlah populasi Maek dan Maek Bako sangat tergantung dari habitatnya, apakah di pekarangan, hutan sekunder/semak belukar atau hutan lebat. Hal ini terkait dengan kompetisi ruang dengan tanaman hutan. Namun hasil wawancara dengan instansi terkait, Maek dan Maek Bako masih dapat mentolerir naungan hingga 55-65\% sehingga sejauh ini masih ada ruang untuk bertumbuh, kedua tanaman ini masih dapat berproduksi dengan baik walaupun dalam kondisi asupan cahaya matahari yang kurang maksimal.

Hasil wawancara dengan responden kunci dan instansi terkait, khususnya Dinas Pertanian Tanaman Pangan Kabupaten Belu, diketahui bahwa Maek Bako/porang saat ini dalam program pengembangan oleh pemerintah Kabupaten Belu sekitar 150 ha dalam musim tanam 2017. Dengan demikian, maka sebaran tanaman porang lebih teratur karena sudah dibudidayakan dengan jarak tanam $1 \mathrm{~m}$ x $1 \mathrm{~m}$ di kawasan hutan kemasyarakatan dan di pekarangan/kebun.

3.3. Peluang Ekonomi Tanaman Suweg (Maek) dan Porang (Maek Bako)-Analisa Potensi Produksi dan Biaya Produksi

3.3.1.. Potensi Produksi dan Biaya Produksi Non Budidaya

Gambaran hasil perlakuan transek garis pada kawasan tumbuh tanaman suweg (Maek) di 8 Kecamatan sampel menunjukkan bahwa ada perbedaan jumlah populasi (tanaman) suweg (Maek) antara plot I, plot II dan plot III, serta ada perbedaan jumlah populasi (tanaman) antar Kecamatan. Demikian juga dengan berat umbi suweg (Maek) 
untuk umur tanaman 3-4 tahun beratnya berkisar antara $3-5 \mathrm{~kg} / \mathrm{umbi}$.

Data rerata hasil transek menunjukkan bahwa dalam kawasan $10 \mathrm{~m} \mathrm{x} 10 \mathrm{~m}$ jumlah populasi (tanaman) suweg (Maek) sebanyak 46 pohon dengan rerata berat umbi adalah $4 \mathrm{~kg}$. Hal ini berarti bahwa dalam luasan $100 \mathrm{~m}^{2}$, potensi produksi tanaman suweg (Maek) sebesar $184 \mathrm{~kg}$ umbi basah. Untuk potensi produksi setiap hektar (ha) tanaman suweg (Maek) di Kabupaten Belu adalah sebesar 18,4 ton umbi basah untuk setiap 3-4 tahun setelah tumbuh. Dengan demikian maka kawasan hutan dan atau ladang/kebun yang ada di 12 Kecamatan di Kabupaten Belu, mempunyai potensi produksi suweg (Maek) yang cukup besar tanpa dibudidaya dan tanpa biaya produksi, yang dapat dioptimalkan sebagai tanaman alternatif pangan lokal sumber karbohidrat.

Sedangkan untuk Tanaman Porang (Maek Bako) diketahui ada perbedaan jumlah populasi (tanaman) porang (Maek Bako) antara plot I, plot II dan plot III, serta ada perbedaan jumlah populasi (tanaman) antar Kecamatan. Demikian juga, berat umbi porang (Maek Bako) untuk umur tanaman 3-4 tahun beratnya berkisar antara 3-5 kg/umbi basah.

Data rerata hasil transek menunjukkan bahwa dalam kawasan $10 \mathrm{~m}$ x $10 \mathrm{~m}$ jumlah populasi (tanaman) porang (Maek Bako) sebanyak 51 pohon dengan rerata berat umbi adalah $4 \mathrm{~kg}$. Hal ini berarti bahwa dalam luasan $100 \mathrm{~m}^{2}$, potensi produksi tanaman porang (Maek Bako) sebesar $204 \mathrm{~kg}$ umbi basah. Dengan demikian maka potensi produksi setiap hektar (ha) tanaman porang (Maek Bako) di Kabupaten Belu adalah sebesar 20,4 ton umbi basah untuk setiap 3-4 tahun setelah tumbuh. Dengan demikian, pada kawasan hutan dan atau ladang/kebun yang ada di 12 Kecamatan di Kabupaten Belu, terdapat potensi produksi porang (Maek Bako) yang cukup besar tanpa dibudidaya dan tanpa biaya produksi, yang dapat dioptimalkan sebagai tanaman bernilai ekonomis.

Data satatistik Kabupaten Belu dalam Angka Tahun 2015 menunjukan bahwa ada potensi kawasan hutan seluas $41.769,79$ ha yang tersebar di 10 Kecamatan, terdiri atas hutan lindung seluas 40.822 , 88 ha dan hutan produksi seluas 946,91 ha, dengan demikian berdasarkan data statistik, ada potensi produksi suweg (Maek) dan porang (Maek Bako) non budidaya yang dapat tumbuh dan menghasilkan produksi di kawasan hutan lindung dan kawasan hutan produksi yang tersebar di 10 Kecamatan di Kabupaten Belu seluas 41.769,79 ha. Produksi Suweg (Maek) dapat mendukung ketersediaan pangan lokal alternatif sebagai sumber kabohidrat dan produksi porang (Maek Bako) dapat mendukung peningkatan pendapatan masyarakat.

\section{3..2 Potensi Produksi dan Biaya Produksi Porang (Maek Bako) Budidaya}

Mulai Tahun 2017, khusus porang (Maek Bako) dibudidayakan oleh oleh Pemerintah Kabupaten Belu melalui Dinas Tanaman Pangan, Hortikultural dan Perkebunan Kabupaten Belu melalui sumber dana APBD Kabupaten Belu murni seluas 50 ha dan melalui sumber dana APBD Kabupaten Belu perubahan seluas 100 ha.

Kegiatan budidaya tanaman porang (Maek Bako) di Kabupaten Belu Tahun 2017, dilakukan secara generatif, dengan menggunakan katak/bintil dan secara vegetatif dengan menggunakan umbi. Jarak tanam yang digunakan adalah $1 \mathrm{x} 1 \mathrm{~m}$, dengan kedalaman $30 \mathrm{~cm}$, panjang $40 \mathrm{~cm}$ dan lebar $40 \mathrm{~cm}$. Porang merupakan tanaman yang hasilnya baru diperoleh setelah mencapai periode tumbuh 3 kali atau identik dengan 3 tahun. Tanaman porang hanya mengalami pertumbuhan selama 5 sampai 6 bulan (pada musim hujan dengan umur panen berbeda antara yang dibudidayakan secara vegetatif 3 tahun dan generatif 4 tahun.

Porang (Maek Bako) yang dibudidayakan dapat dipanen rata-rata hasil per batang berat umbinya antara 2,5 sampai $5 \mathrm{~kg}$, dengan rata-rata produksi umbi porang berkisar antara 7 sampai 25 ton/ha umbi basah (Siti Mutmaidah, 2015). Dengan demikian potensi produksi porang (Maek Bako) yang dibudidayakan di Kabupaten Belu Tahun 2017 seluas 150 ha (asumsi $80 \%$ tumbuh dan produktivitas 3 $\mathrm{kg} /$ batang), akan dipanen mulai Tahun 2020 sebesar 3.600 ton.

Untuk budidaya porang (Maek Bako) di Kabupaten Belu Tahun 2017, biaya produksi yang digunakan adalah untuk membeli benih/bibit porang meliputi bintil/katak $25 \mathrm{~kg} / \mathrm{ha}$ sebesar Rp. 3.125.000 dan umbi $500 \mathrm{~kg} / \mathrm{ha}$ sebesar Rp. 25.000.000,-., sedangkan biaya lainnya baik itu biaya tetap maupun biaya variabel tidak ada.

\subsection{Analisa Ekonomi Usaha Tani}

Dari hasil analisa ekonomi/ usaha tani menunjukkan bahwa dalam usaha tani non budidaya tanaman suweg (Maek) dan porang (Maek Bako), biaya produksi yang dikeluarkan untuk transportasi pengangkutan hasil gaplek suweg/porang dengan rata-rata Rp. 15.000/100 kg dan biaya karung Rp. $5.500 /$ karung serta biaya tenaga kerja untuk panen dan pasca panen 9 HOK $(1 \mathrm{HOK}=\mathrm{Rp}$. 60.000). Dalam $100 \mathrm{~kg}$ umbi basah apabila dikeringkan untuk menjadi gaplek menjadi $17 \mathrm{~kg}$. Untuk produksi suweg (Maek) umbi basah sebanyak $18.400 \mathrm{~kg}$ menjadi gaplek (kering) sebanyak $3.128 \mathrm{~kg}$ dan untuk produksi porang (make bako) umbi basah sebanyak $20.140 \mathrm{~kg}$ menjadi gaplek (kering) sebanyak $3.468 \mathrm{~kg}$. Pemasaran masih hanya dalam satu produk saja yaitu gaplek dengan harga rata-rata Rp. $21.000 / \mathrm{kg}$, yang dipasarkan pada UD Gajah Mada dan UD Paris Indah.

Penerimaan dari hasil produksi dimulai pada tahun ketiga dan tahun-tahun selanjutnya ada 
penerimaaan tanpa ditanam kembali umbinya. Total pendapatan setiap hektar untuk suweg (Maek) sebesar Rp. 31.490.800 atau Rp. 2.624.233/bulan. Sedangkan total pendapatan setiap hektar untuk porang (Maek Bako) sebesar Rp. 35.060.800 atau Rp. 2.921.733/ bulan. Nilai R/C Ratio > 1 untuk suweg (Maek) dan porang (Maek Bako) non budidaya berarti usaha ini menguntungkan. Nilai B/C Ratio > 1 untuk suweg (Maek) dan porang (Maek Bako) non budidaya berarti usaha ini layak atau memberi manfaat.

Mulai Tahun 2017, melalui Dinas Tanaman Pangan, Hortikultura dan Perkebunan Kabupaten Belu dibudidayakan tanaman porang (Maek Bako) seluas 150 ha pada 3 Kecamatan, 8 Desa dengan 10 kelompok tani. Untuk mengetahui peluang ekonomis dari porang (Maek Bako) yang dibudidayakan perlu dilakukan analisa ekonomi usahatani.

Hasil analisis ekonomi/ usahatani menunjukkan bahwa dalam usahatani budidaya tanaman porang (Maek Bako), biaya produksi yang dikeluarkan adalah untuk benih sebesar Rp. 31.638.200, transportasi pengangkutan hasil gaplek suweg/porang dengan rata-rata Rp. 15.000/100 kg dan biaya karung Rp.5.500/karung serta biaya untuk tenaga kerja tahun pertama untuk kegiatan pengolahan tanah dan penanaman $12 \mathrm{HOK}$, tahun kedua untuk kegiatan penyiangan dan pengendalian OPT $11 \mathrm{HOK}$ dan tahun ketiga untuk kegiatan penyiangan, pengendalian OPT, panen dan pasca panen $22 \mathrm{HOK}$. $100 \mathrm{~kg}$ umbi basah, apabila dikeringkan akan menjadi gaplek sebanyak $17 \mathrm{~kg}$. Untuk produksi porang (Maek Bako) umbi basah sebanyak $24.000 \mathrm{~kg}$ menjadi gaplek (kering) sebanyak $4.080 \mathrm{~kg}$. Pemasaran masih dalam satu produk saja yaitu gaplek dengan harga rata-rata Rp. $21.000 / \mathrm{kg}$, yang dipasarkan pada UD Gajah Mada dan UD Paris Indah.

Penerimaan dari hasil produksi dimulai pada tahun ketiga dan tahun-tahun selanjutnya ada penerimaaan tanpa ditanam kembali umbinya. Total pendapatan setiap hektar untuk porang (Maek Bako) budidaya di Kabupaten Belu sebesar Rp.54.041.800 atau Rp. 4.503.483/bulan. Nilai R/C Ratio 2,71 > 1 berarti usaha ini menguntungkan. Nilai B/C Ratio $1,71>1$ berarti usaha ini layak atau memberi manfaat. Pada tahun 2017 dibudidayakan sebanyak 150 ha berarti di Kabupaten Belu pada Tahun 2020, kurang lebih ada produksi umbi basah porang (Maek Bako) sebanyak 3.600 ton atau 612 ton gaplek porang (Maek Bako) atau ada penerimaan dari luasan tanam 150 ha sebesar Rp. 12. 852.000.000,--

Hasil analisa juga menunjukan bahwa budidaya porang (Maek Bako) pada tahun 2017 di Kabupaten Belu masih belum didukung dengan paket teknologi budidaya yang lengkap (hanya untuk pembelian benih saja). Untuk mendukung peningkatan produktivitas hasil porang budidaya agar hasilnya dapat berbeda dengan non budidaya, maka pengembangan selanjutnya perlu dilengkapi paket budidaya yang lengkap meliputi benih, pupuk, pestisida sampai dengan penanganan panen, pasca panen serta didukung dengan teknologi pengolahan untuk meningkatkan nilai ekonomis serta pemasaran.

Hasil penelitian lain menunjukkan bahwa porang (Maek Bako), selain diolah menjadi gaplek juga dapat diolah menjadi chip porang dengan harga sekitar Rp. 27.000/kg, dan tepung porang dengan harga dapat mencapai Rp. 250.000/kg. Tepung porang yang telah dimurnikan dapat dimanfaatkan untuk industri farmasi dan makanan. Hal ini dikarenakan tepung porang mempunyai glukomanan yang baik bagi kesehatan. Dengan demikian apabila hasil produksi suweg (Maek) dan porang (Maek Bako) di Kabupaten Belu diolah menjadi produk lain (chip dan tepung) maka akan dapat memberi nilai tambah penerimaan/pendapatan.

\subsection{Potensi Suweg (Maek) dan Porang (Maek Bako) sebagai Pangan Lokal}

Sebagai potensi pangan lokal sumber karbohidrat dilakukan uji kandungan gizi kerjasama dengan Laboratorium Riset Terpadu Undana Kupang, dengan keragaman kandungan gizinya sebagai berikut :

Hasil Analisa Kandungan Gizi Suweg (Maek) dan Porang (Maek Bako) Dalam 100 gam

\begin{tabular}{|c|c|c|c|c|}
\hline \multirow[t]{2}{*}{ No } & \multirow[t]{2}{*}{ Parameter } & \multirow[t]{2}{*}{ Satuan } & \multicolumn{2}{|c|}{$\begin{array}{c}\text { Kandungan Gizi } \\
\text { Per } 100 \text { gram }\end{array}$} \\
\hline & & & $\begin{array}{c}\text { Suweg } \\
\text { (Maek) }\end{array}$ & $\begin{array}{c}\text { Porang } \\
\text { (Maek } \\
\text { Bako) }\end{array}$ \\
\hline 1. & $\begin{array}{l}\text { Berat } \\
\text { Bahan yang } \\
\text { Dapat di } \\
\text { makan }\end{array}$ & $\%$ & 89,30 & 85,12 \\
\hline 2. & Energi & Kkal & 89,32 & 81,20 \\
\hline 3. & Kadar Air & $\%$ & 77,09 & 81,16 \\
\hline 4. & Karbohidrat & gram & 14,18 & 10,28 \\
\hline 5. & Protein & gram & 5,90 & 6,60 \\
\hline 6. & Lemak & gram & 1,00 & 1,50 \\
\hline 7. & $\begin{array}{l}\text { Kadar abu } \\
\text { (mineral) }\end{array}$ & $\%$ & 1,83 & 0,46 \\
\hline 8. & $\mathrm{Cu}$ & $\mathrm{mg}$ & 1,60 & 1,30 \\
\hline 9. & $\mathrm{Fe}$ & $\mathrm{mg}$ & 6,93 & 5,77 \\
\hline
\end{tabular}

Sumber : Laboratorium Riset Terpadu Universitas Nusa Cendana Kupang.

Data pada Tabel diatas menunjukkan bahwa ada perbedaan kandungan gizi antara suweg (Maek) dan porang (Maek Bako) di Kabupaten Belu, dengan suweg (Maek) memiliki keragaman kandungan gizi yang lebih tinggi dari pada porang (Maek Bako) serta keragaman kandungan gizinya juga berbeda dengan suweg dan porang yang tumbuh di daerah lain di 
Indonesia. Pada sisi lain, pengolahan porang (Maek Bako) membutuhkan perlakuan khusus (pencucian dengan etanol) dan prosesnya lebih hati-hati karena porang (Maek Bako) mengandung kalsium oksalat yang dapat menyebabkan gatal pada kulit dan mengendap di ginjal serta merusak hati. Sedangkan suweg (Maek), pengolahannnya lebih mudah dibandingkan dengan porang (Maek Bako). Pada sisi lain perbandingan kandungan gizi dari suweg (Maek) dan porang (Maek Bako) dengan pangan sumber karbohidrat lainnya cukup bervariasi dengan cukup banyak parameter yang suweg (Maek) dan porang (Maek Bako) lebih rendah. Untuk jelasnya dapat dilihat pada tabel dibawah ini.

\begin{tabular}{|c|c|c|c|c|c|c|c|c|}
\hline \multirow{2}{*}{ No } & \multirow[b]{2}{*}{$\begin{array}{l}\text { Bahan } \\
\text { Pangan }\end{array}$} & \multirow[b]{2}{*}{$\begin{array}{c}\text { Ener } \\
\text { gi }\end{array}$} & \multirow[b]{2}{*}{$\begin{array}{l}\text { Prot } \\
\text { ein }\end{array}$} & \multicolumn{2}{|c|}{ Zat Gizi } & \multirow[b]{2}{*}{ Abu } & & \\
\hline & & & & $\begin{array}{c}\text { Za } \\
\text { Lem } \\
\text { ak }\end{array}$ & $\begin{array}{l}\text { Kizi } \\
\text { Karb } \\
\text { ohidr } \\
\text { at }\end{array}$ & & Air & $\begin{array}{l}\text { BDD } \\
(\%)\end{array}$ \\
\hline 1. & Beras & 360 & 6.8 & 0.7 & 78.9 & & 13.0 & 100 \\
\hline 2. & Porang & 81,20 & 6,60 & 1,5 & 10,28 & 0,46 & $\begin{array}{r}81,1 \\
6\end{array}$ & 85,12 \\
\hline 3. & Suweg & 89,32 & 5,90 & 1,00 & 14,18 & 1,83 & $\begin{array}{r}77,0 \\
9\end{array}$ & 89,30 \\
\hline 4. & $\begin{array}{l}\text { Singkong } \\
\text { (putih) }\end{array}$ & 146 & 1.2 & 0.3 & 34.7 & - & 62.5 & 75 \\
\hline 5. & $\begin{array}{l}\text { Singkong } \\
\text { (kuning) }\end{array}$ & 157 & 0.6 & 0.3 & 37.9 & - & 60.0 & 75 \\
\hline 6. & $\begin{array}{l}\text { Uwi/ } \\
\text { Gadung }\end{array}$ & 201 & 2.0 & 0.2 & 79.8 & - & - & 100 \\
\hline 7. & $\begin{array}{l}\text { Shorgum } \\
\text { Lena }\end{array}$ & 395 & 20.3 & 8.73 & 58.8 & 6.6 & 5.6 & 100 \\
\hline 8. & $\begin{array}{l}\text { Shorgum } \\
\text { Jagung } \\
\text { Rote }\end{array}$ & 385 & 10.6 & 7.4 & 69.0 & 1.1 & 11.9 & 100 \\
\hline 9. & Jagung & 365 & 9,0 & 4,7 & 74 & - & - & - \\
\hline
\end{tabular}

GMSK Laboratorium Riset Terpadu Undana dan Laboratorium Teknologi Pangan dan Gizi, IPB

Data pada Tabel tersebut menunjukkan bahwa kandungan energi dan karbohidrat dari suweg (Maek) dan porang (Maek Bako) di Kabupaten Belu lebih rendah dari kandungan gizi beras, shorgum, jagung dan dan beberapa jenis ubi-ubian, yang juga merupakan pangan sumber karbohidrat. Kandungan protein suweg (Maek) dan porang (Maek Bako) lebih rendah dari beras, shorgum dan jagung, akan tetapi lebih tinggi dari jenis ubi-ubian lainnya. Keragaman data tabel 11 juga menggambarkan bahwa kandungan karbohidrat suweg (Maek) dan porang (Maek Bako) kurang lebih hanya 19,16\% jika dibandingkan dengan kandungan karbohidrat beras dan jagung, sehingga apabila suweg (Maek) dan porang (Maek Bako) dijadikan sebagai alternatif pangan sumber karbohidrat perlu diatur pola konsumsinya agar asupan kecukupan energi dan karbohidratnya dapat mencapai kecukupan gizi beras atau jagung serta dilakukan penataan pola makan harian antara makan pagi - selingan - makan siang - selingan - makan malam. Sedangkan kebutuhan zat besi (Fe) tergantung pada jenis kelamin dan umur dengan variasi untuk orang dewasa antara 8,5 sampai 18,9 $\mathrm{mg} / \mathrm{hari}$. Hal ini berarti kandungan zat besi $(\mathrm{Fe})$ pada suweg (Maek) dan porang (Maek Bako) per 100 gram adalah $6,93 \mathrm{mg}$ dan 5,77 mg cukup tinggi untuk memenuhi variasi standar kebutuhan orang dewasa. Manusia membutuhkan zat tembaga $(\mathrm{Cu})$ perhari adalah $0,05 \mathrm{mg} / \mathrm{kg}$ berat badan, hal ini berarti dengan kandungan zat tembaga pada suweg (Maek) dan porang (Maek Bako) per 100 gram adalah 1, 60 $\mathrm{mg}$ dan 1,30 mg masih berada dalam batas ambang kebutuhan zat tembaga bagi tubuh manusia.

\section{Kesimpulan}

1. Terdapat dua jenis tanaman talas-talasan genus Amorphophalus yang ada di Kabuapetan Belu yakni Maek (Me Loi/Maek Diak) atau Suweg dan Maek Bako (Me Jon/Maek Fuik) atau Porang.

2. Maek dan Maek Bako menyebar di delapan kecamatan di Kabupaten Belu dengan rata-rata kepadatan populasi sedang, dan menyebar di sepertiga hingga setengah luas wilayah desa/kecamatan, dengan pola sebaran hampir berimbang antara Maek dan Maek Bako.

3. Ada potensi produksi suweg (Maek) dan porang (Maek Bako) non budidaya yang dapat tumbuh dan menghasilkan produksi di kawasan hutan lindung dan kawasan hutan produksi yang tersebar di 10 Kecamatan di Kabupaten Belu seluas 41.769,79 ha. Produksi Suweg (Maek) untuk mendukung alternatif ketersediaan pangan lokal sumber kabohidrat dan produksi porang (Maek Bako) untuk mendukung peningkatan pendapatan masyarakat.

4. Total pendapatan setiap hektar untuk suweg (Maek) sebesar Rp. 31.490 .800 atau Rp. 2.624.233/bulan. Sedangkan total pendapatan setiap hektar untuk porang (Maek Bako) sebesar Rp. 35.060.800 atau Rp. 2.921.733/bulan. Nilai R/C Ratio > 1 untuk suweg (Maek) dan porang (Maek Bako) non budidaya berarti usaha ini menguntungkan. Nilai B/C Ratio > 1 untuk suweg (Maek) dan porang (Maek Bako) non budidaya berarti usaha ini layak atau memberi manfaat.

5. Total pendapatan setiap hektar untuk porang (Maek Bako) budidaya di Kabupaten Belu sebesar Rp. 54.041.800 atau Rp. 4.503.483/bulan. Nilai R/C Ratio 2,71 > 1 berarti usaha ini menguntungkan . Nilai B/C Ratio 1,71 $>1$ berarti usaha ini layak atau memberi manfaat. Pada tahun 2017 dibudidayakan sebanyak 150 ha berarti di Kabupaten Belu pada Tahun 2010, kurang lebih ada produksi umbi basah porang (Maek Bako) sebanyak 3.600 ton atau 612 ton gaplek porang (Maek Bako) atau ada penerimaan dari luasan tanam 150 ha sebesar Rp. 12. 852.000.000,--

6. Berdasarkan Kandungan gizi dan cara pengolahannya, suweg (Maek) sebaiknya diprioritaskan sebagai pangan lokal alternatif untuk dikonsumsi sedangkan porang (Maek Bako) diproritaskan sebagai pangan ekonomis untuk menunjang pendapatan masyarakat, suweg (Maek) sebaiknya dikonsumsi sebagai 
makanan selingan pagi dan selingan sore dengan meningkatkan keanekaragaman produk hasil olahan untuk dikonsumsi, serta pengolahan porang sebagai pangan ekonomis perlu ditingkatkan keanekaragaman produknya (jangan hanya dijual dalam bentuk gaplek saja), sehingga dapat memberikan nilai tambah bagi pendapatan masyarakat.

\section{Ucapan Terima Kasih (Acknowledgments)}

Terima kasih peneliti ucapkan kepada Badan Perencanaan Pembangunan Penelitian dan Pengembangan Daerah yang telah mendanai penelitian. Secara khusus Peneliti menyampaikan terima kasih kepada Nixon M. Balukh yang menjadi rekan diskusi utama untuk memperkaya penulisan.

\section{Referensi}

Björk, Peter, \& Kauppinen-Räisänen, Hannele. (2016). Local food: a source for destination attraction. International Journal of Contemporary Hospitality, 28(1), 177-194. doi: 10.1108/IJCHM-05-2014-0214

Bryld, Erik. (2003). Potentials, problems, and policy implications for urban agriculture in developing countries. Agriculture and Human Values, 20(1), 79-86.

Carney, Patricia A., Hamada, Janet L., Rdesinski, Rebecca, Sprager, Lorena, Nichols, Katelyn R., Liu, Betty Y., Shannon, Jacklien. (2012). Impact of a Community Gardening Project on Vegetable Intake, Food Security and Family Relationships: A Community-based Participatory Research Study. Journal Community Health, 37, 874-881. doi: 10.1007/s10900-011-9522-z

Charatsari, Chrysanthi, Kitsios, Fotis, Stafyla, Amalia, Aidonis, Dimitrios, \& Lioutas, Evagelos. (2018). Antecedents of farmers' willingness to participate in short food supply chains. British Food Journal, 120(10), 2317-2333. doi: 10.1108/BFJ-092017-0537

Conroe, Scott. (1999). Community food security-ensuring food access locally. Human Ecology Forum, 27(1), 14-16.

Dimitri, Carolyn, Oberholtzer, Lydia, \& Pressman, Andy. (2015). Urban agriculture: connecting producers with consumers. British Food Journal, 118(3), 603-617. doi: 10.1108/BFJ06-2015-0200

Maughan, Chris, Pedersen, Rebecca Laycock, \& Pitt, Hannah. (2018). The problems, promise and pragmatism of community food growing. Renewable Agriculture and Food Systems, 33(6), 497-502. doi: $10.1017 / \mathrm{S} 1742170518000200$
Navin, Mark C. (2014). Local Food and International Ethics. J Agric Environ Ethics, 27, 349-368. doi: 10.1007/s10806-014-9492-0

Pearson, Leonie J., Pearson, Linda, \& Pearson, Craig J. (2010). Sustainable urban agriculture: stocktakeand opportunities. International Journal of Agricultural Sustainability, 8(1), 7-19. doi: 10.3763/ijas.2009.0468

Peterson, Gregory R. (2013). Is Eating Locally a Moral Obligation? J Agric Environ Ethics, 26, 421-437. doi: 10.1007/s10806-0129397-8

Roehrig, Lucy. (2011). The Rise Of The Locavore. Library Journal, 136(6), 1-10.

Schnell, Steven M. (2013). Food miles, local eating, and community supported agriculture:putting local food in its place. Agric Hum Values, 30, 615-628. doi: 10.1007/s10460-013-9436-8

Trivette, Shawn A. (2015). How local is local? Determining the boundaries of local food in practice. Agric Hum Values, 32(1), 475490. doi: 10.1007/s10460-014-9566-7

Zeuw, H. De, Veenhuizen, R. Van, \& Dubbeling, M. (2011). Foresight project on global food and farming futures: The role of urban agriculture in building resilient cities in developing countries. Journal of Agricultural Science, 149, 153-163. doi: $10.1017 / \mathrm{S} 0021859610001279$ 
